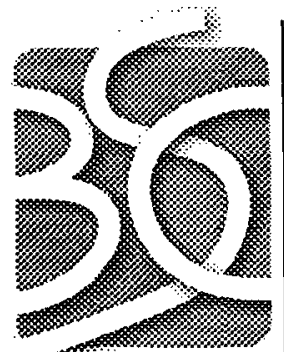

BECHTEL SAIC COMPANVLC

QA: NA

BABBAA000-01717-5705-00001 REV 01

April 2001

\title{
Electrical Switchgear Building No. 5010-ESF Fire Hazards Technical Report
}

By

N.M. Ruonavaara

Prepared for:

U.S. Department of Energy

Yucca Mountain Site Characterization Office

P.O. Box 30307

North Las Vegas, Nevada 89036-0307

Prepared by:

Bechtel SAIC Company, LLC

1180 Town Center Drive

Las Vegas, Nevada 89144

Under Contract Number

DE-AC08-01NV1210 
This report was prepared as an account of work sponsored by an agency of the United States Government. Neither the United States Government nor any agency thereof, nor any of their employees, nor any of their contractors, subcontractors or their employees, makes any warranty express or implied, or assumes any legal liability or responsibility for the accuracy, completeness, or any third party's use or the results of such use of any information, apparatus, product, or process disclosed, or represents that its use would not infringe privately owned rights. Reference herein to any specific commercial product, process, or service by trade name, trademark, manufacturer, or otherwise, does not necessarily constitute or imply its endorsement, recommendation, or favoring by the United States Government or any agency thereof or its contractors or subcontractors. The views and opinions of authors expressed herein do not necessarily state or reflect those of the United States Government or any agency thereof. 


\section{Electrical Switchgear Building No. 5010-ESF Fire Hazards Technical Report}

Prepared by:

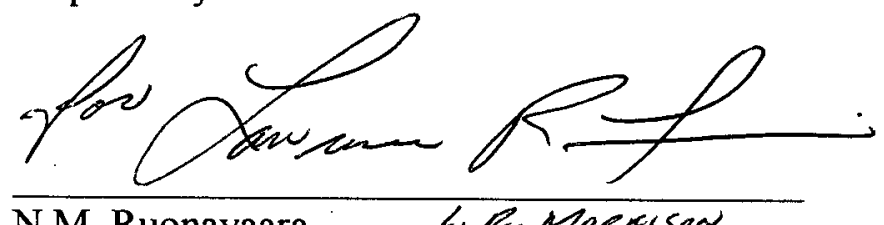

N.M. Ruonavaara L. R. MoRerson

Test Facilities Design TFD MGR.

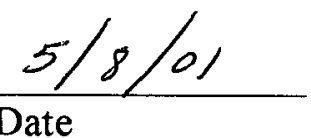

Checker Concurrence:

John Kubick

John Kubicek

$05-08-01$

Product Checking Group

Date

Approved by:
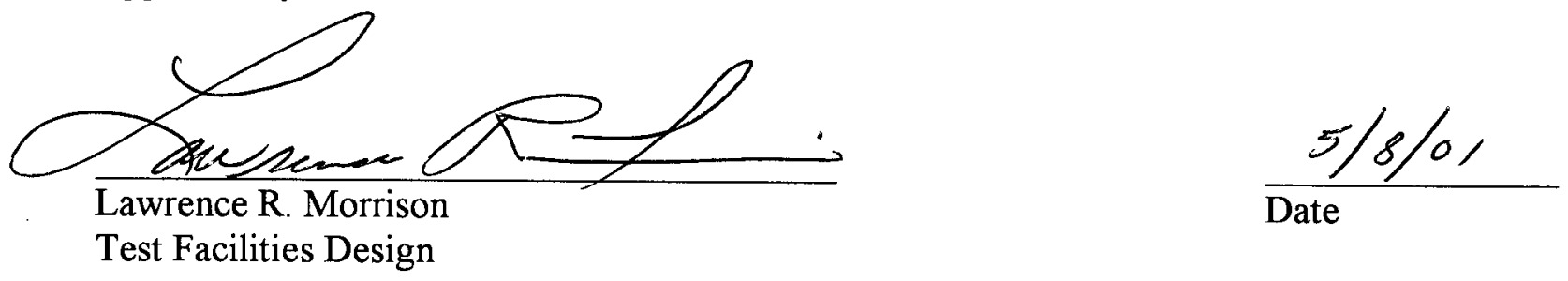
INTENTIONALLY LEFT BLANK 


\section{TABLE OF CONTENTS}

1. PURPOSE

2. SCOPE

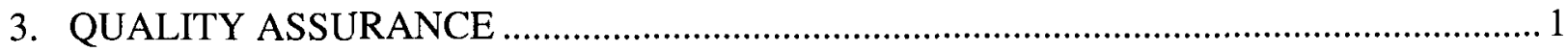

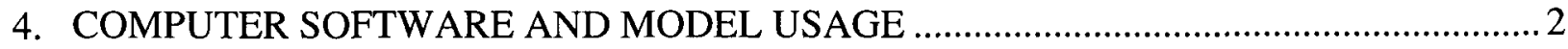

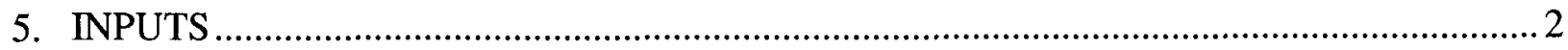

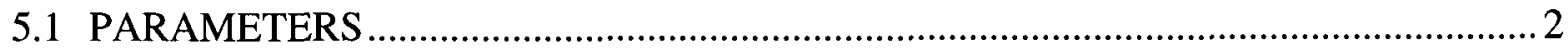

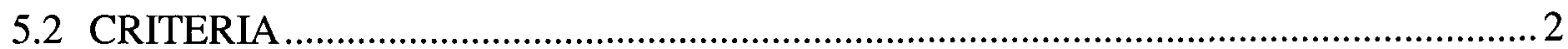

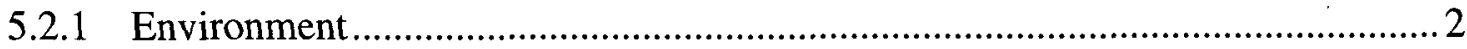

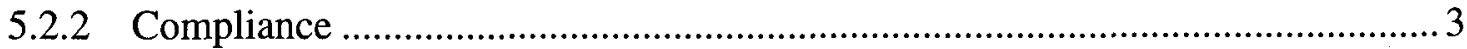

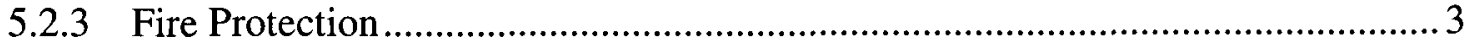

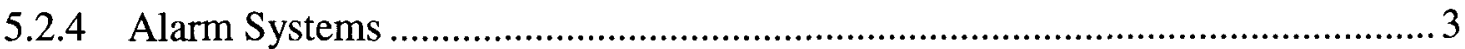

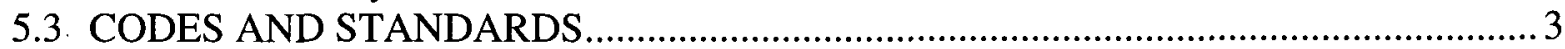

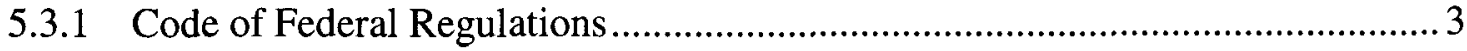

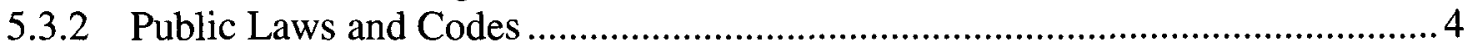

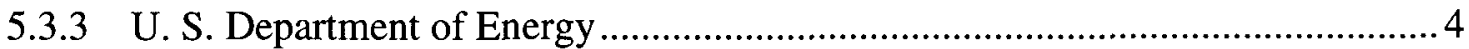

5.3.4 National Fire Protection Association ......................................................... 4

5.3.5 International Conference of Building Officials............................................ 4

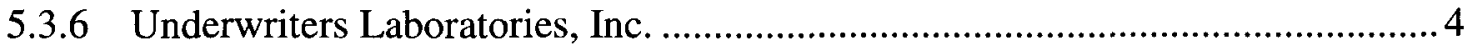

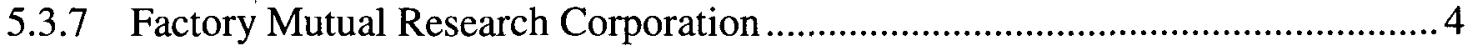

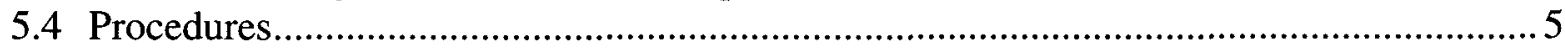

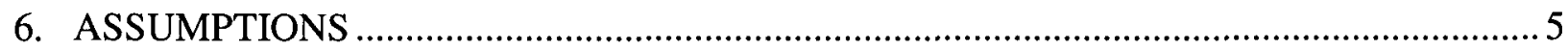

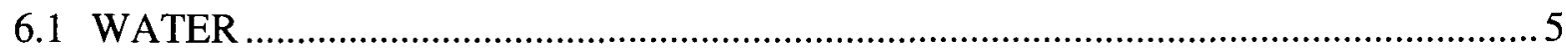

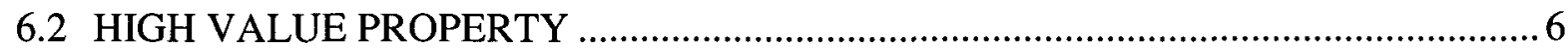

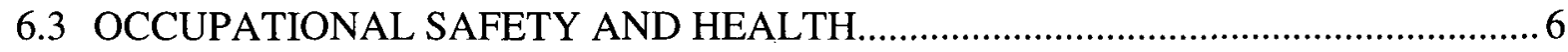

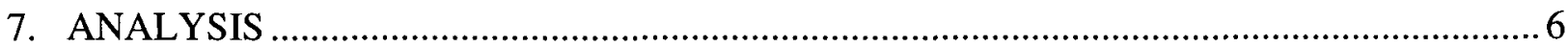

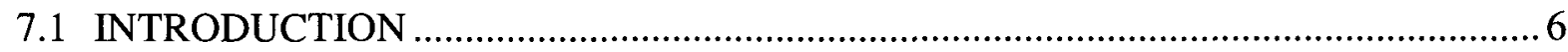

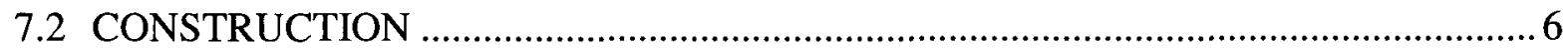

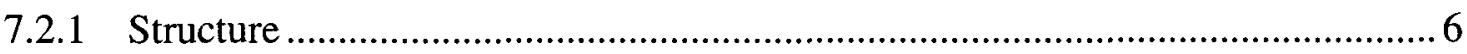

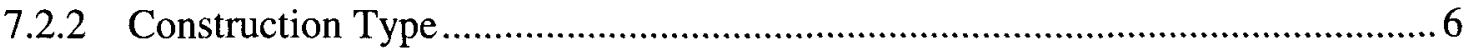

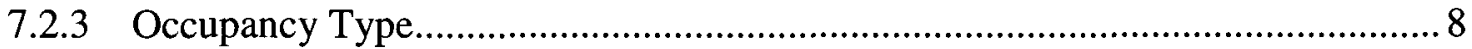

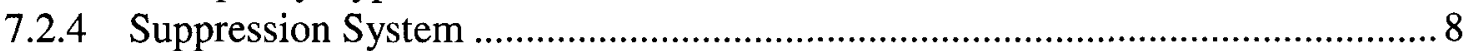

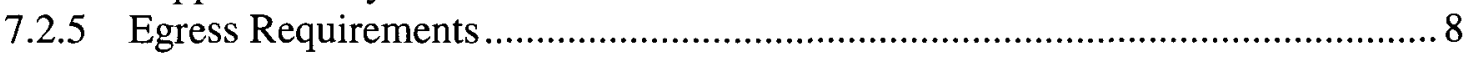

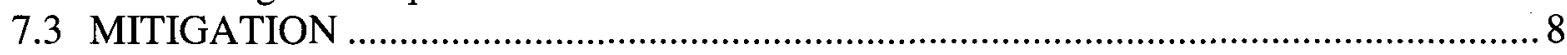

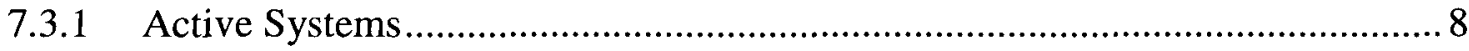

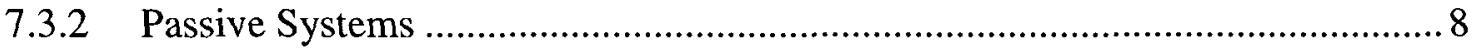




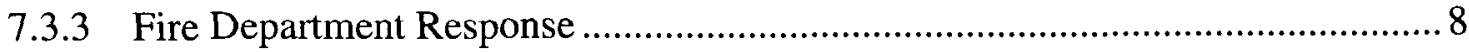

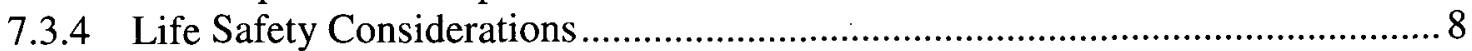

7.3.5 Special Considerations .................................................................................. 9

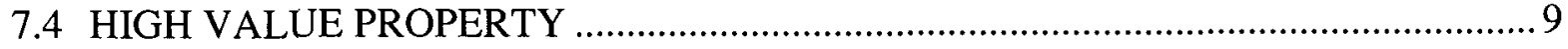

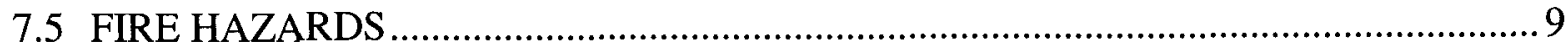

7.5.1 North Fire Area - Craft Shop Area ...............................................................

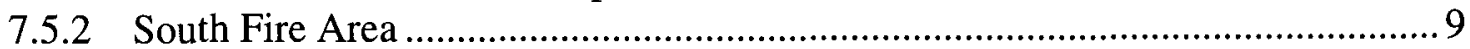

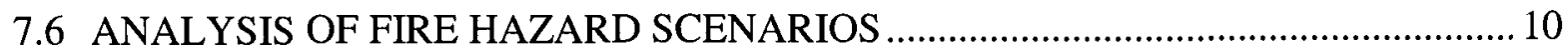

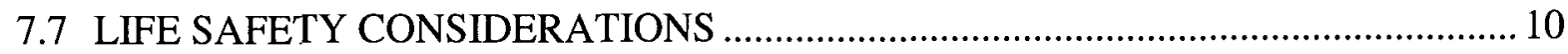

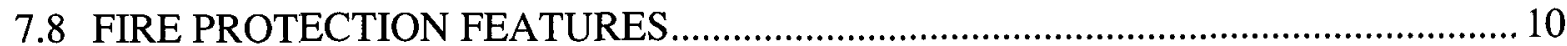

7.8.1 Fire Suppression and Extinguishing............................................................... 10

7.8.2 Fire Water Supply and Distribution Piping......................................................... 11

7.8.3 Fire Detection and Alarm System ...................................................................... 12

7.9 POTENTIAL FOR A TOXIC, BIOLOGICAL, AND/OR RADIATION

INCIDENT DUE TO A FIRE ……………………................................................... 12

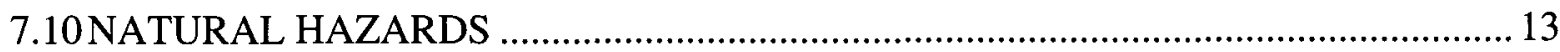

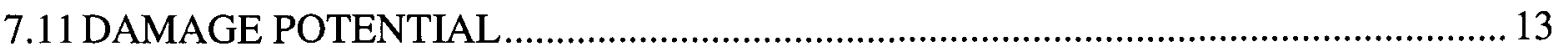

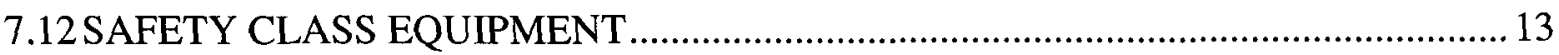

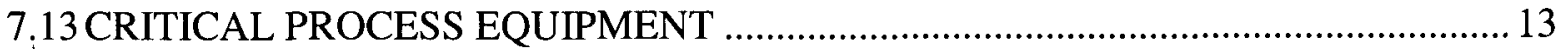

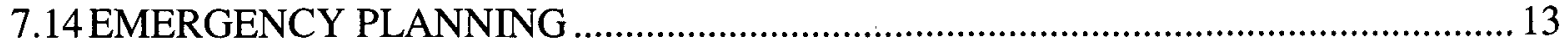

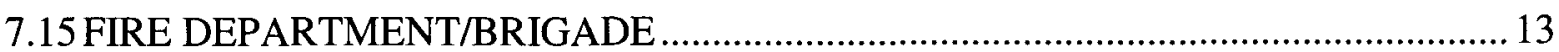

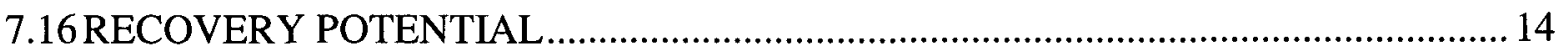

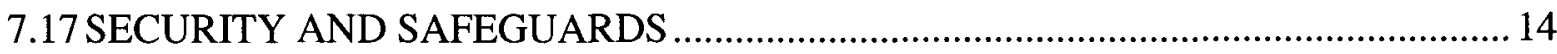

7.18EXPOSURE FIRE POTENTIAL AND THE POTENTIAL FOR FIRE SPREAD BETWEEN TWO FIRE AREAS ………............................................ 14

7.19EFFECTS OF SIGNIFICANT FIRE SAFETY DEFICIENCIES ON FIRE RISK ........ 14

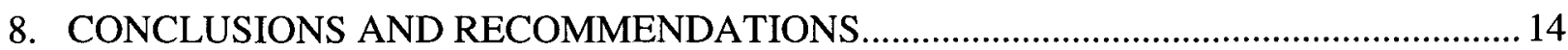

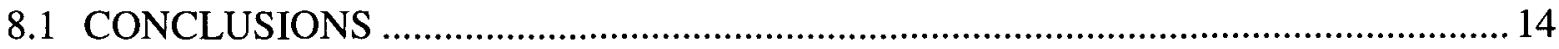

8.1.1 Fire Occurrence...................................................................................... 15

8.1.2 Radioactive and Hazardous Materials............................................................ 15

8.1.3 Vital DOE Programs .............................................................................. 15

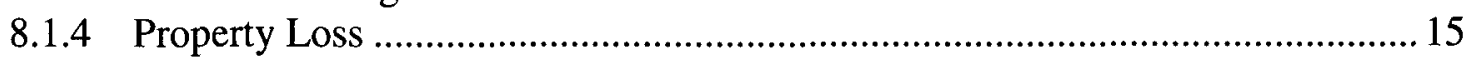

8.1.5 Critical Process Controls and Safety Class Systems.......................................... 15

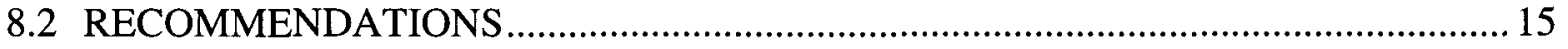

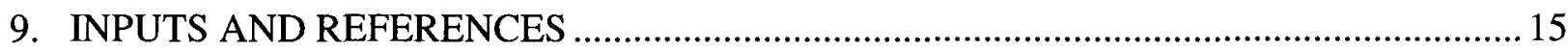

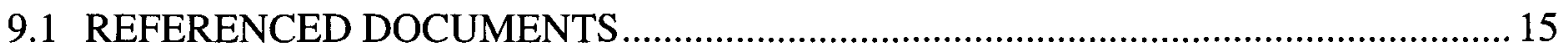

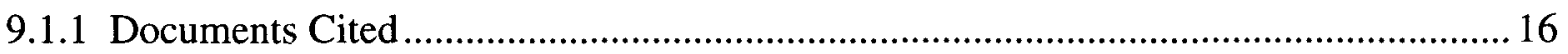




\section{FIGURES}

Page

1. ESF Electrical Switchgear Building Fire Protection Plan and Section................................ 7 


\section{ACRONYMS AND ABBREVIATIONS}

DOE U.S. Department of Energy

EFS Exploratory Studies Facility

ESFDR Exploratory Studies Facility Design Requirements

NTS Nevada Test Site 


\section{PURPOSE}

The purpose of this Fire Hazards Analysis Technical Report (hereinafter referred to as Technical Report) is to assess the risk from fire within individual fire areas to ascertain whether the U.S. Department of Energy (DOE) fire safety objectives are met. The objectives, identified in DOE Order 420.1, Change 2, Fire Safety, Section 4.2, establish requirements for a comprehensive fire and related hazards protection program for facilities sufficient to minimize the potential for:

- The occurrence of a fire or related event

- A fire that causes an unacceptable on-site or off-site release of hazardous or radiological material that will threaten the health and safety of the employees, the public, and the environment

- Vital DOE programs suffering unacceptable interruptions as a result of fire and related hazards

- Property losses from a fire and related events exceeding defined limits established by DOE

- Critical process controls and safety class systems being damaged as a result of a fire and related event.

\section{SCOPE}

The scope of this Technical Report is limited to the two defined fire areas of the Exploratory Studies Facility (ESF) Electrical Switchgear Building No. 5010 and the immediate surrounding areas to verify compliance with DOE Order 420.1, Change 2. The definition of a fire area per DOE G 440.1-5, Implementation Guide for Use with DOE Orders 420.1 and 440.1 Fire Safety Program, is stated as: "A fire area is defined as a location bounded by fire-rated construction, having a minimum fire resistance rating of 2 hours, with openings protected by equivalently-rated fire doors, dampers or penetration seals. The boundaries of exterior fire areas (yard areas) should be as determined by the Authority Having Jurisdiction or delegated authority. Where a facility is not subdivided by fire-rated construction, the fire area should be defined by the exterior walls and roof of the facility." The fire areas identified in this Technical Report are defined as the ESF Electrical Switchgear Building Fire Areas North and Fire Area South. This Technical Report is limited to the Electrical Switchgear Building. The areas surrounding the Electrical Switchgear Building have been analyzed by the Surface Fire Hazards Analysis Technical Report-Constructor Facilities, BAB000000-01717-5705-00016. All exposure fire hazards to the Electrical Switchgear Building are identified in this report.

\section{QUALITY ASSURANCE}

This Technical Report was prepared in accordance with AP-3.11Q, Technical Reports, and the associated Technical Work Plan for Test Facilities Design FYOI Work Activities, (CRWMS 
M\&O 2000b) that was prepared in accordance with AP2.21 Quality Determinations and Planning for Scientific, Engineering and Regulatory Compliance Activities.

Results of the Complete Accurate Technical Baseline (CRWMS M\&O 1999) have determined that the preparation of this Technical Report is not subject to the requirements of the Quality Assurance Requirements and Description, DOE/RW-0333P (DOE 2000). No quality assurance controls are applicable to the items or activities addressed in this Technical Report. [QA: N/A].

The items addressed in this Technical Report are temporary and are, therefore, not classified in accordance with QAP-2-3, Classification of Permanent Items. There are no specific Determination of Importance Evaluation requirements that apply.

\section{COMPUTER SOFTWARE AND MODEL USAGE}

This Technical Report uses off-the-shelf, commercial word processing software in its preparation. No software routines or models are used.

\section{INPUTS}

Inputs for this Technical Report were obtained from the Exploratory Studies Facility Design Requirements (ESFDR) (YMP 1997), and from a site walk-down conducted on May 16, 2000. The results of the walk-down have been incorporated into this document. Additional input was obtained from the Surface Fire Hazards Analysis Technical Report-Constructor Facilities.

\subsection{PARAMETERS}

Not used.

\subsection{CRITERIA}

The Office of Civilian Radioactive Waste Management procedure, AP-ESH-004, Occupational Safety and Health Program, refers to DOE 420.1, Change 2, to establish safety requirements related to fire protection mitigation.

The following fire protection design requirements are applicable to the ESF Electrical Switchgear Building.

\subsubsection{Environment}

The Electrical Switchgear Building modifications and equipment shall be designed to operate under the environmental conditions listed in the ESFDR (YMP 1997). These requirements are described in Sections 3.2.1.2.1.1.A, Fungus, Bacteria, and Algae; 3.2.1.2.1.1.B, Earthquake; 3.2.1.2.1.1.C, High Winds; 3.2.1.2.1.1.D, Grounding; 3.2.1.2.1.1.E, Precipitation; 3.2.1.2.1.1.F, Temperature; 3.2.1.2.1.1.G, Snow; 3.2.1.2.1.1.H, Humidity; 3.2.1.2.1.1.I, Flood; and 3.2.1.2.1.1.J, Sand and Dust. These requirements will be implemented during the design, 
installation, and testing of the Electrical Switchgear Building modifications, including the fire protection systems.

\subsubsection{Compliance}

The ESFDR (YMP 1997) states that fire protection requirements shall be designed in compliance with DOE Order 5480.7A, Fire Protection. This Order has been replaced by DOE Order 420.1, Change 2. The requirements of DOE Order 420.1, Change 2 will be implemented during the design, installation, and testing of the Electrical Switchgear Building fire protection systems.

The Office of Civilian Radioactive Waste Management procedure, AP-ESH-008, Hazards Analysis System, provides guidelines for fire hazards analysis development in accordance with DOE Order 420.1, Change 2.

\subsubsection{Fire Protection}

Electrical Switchgear Building fire protection shall be provided as specified by Sections 3.4.2.1.1.B, Vehicle Access; 3.4.2.1.2.B, Surface Facilities Fire Protection Systems; 3.4.2.5.1, Surface Utilities; 3.4.5.3.1.J, Water Supply, Storage, and Distribution; 3.4.5.2.1.N, Switching and Protective Devices; 3.4.5.2.1P, Surge Protection and Grounding; 3.5.7.1.C, Booster Pump Station; 3.5.9.1C, Tank Size; and 3.5.9.1.D, Tank Volume of the ESFDR (YMP 1997). These requirements will be implemented during the design, installation, and testing of the Electrical Switchgear Building fire protection features and systems.

\subsubsection{Alarm Systems}

To alert on-site and fire fighting personnel of possible dangerous environmental and safety situations, the ESFDR (YMP 1997) describes the system requirements. These requirements are described in Sections 3.4.5.5.1.F, Communications With Underground; 3.4.5.5.1.I, Public Address System; 3.4.5.5.1.L, Communication With NTS Fire Response and Nye County; 3.5.7.1.B, Pump Rate; 3.5.7.1.C, Pump Demand; and 3.6.2.1.C, Facility Monitoring \& Control System of the ESFDR (YMP 1997), requiring that alarm and communication systems be provided. These requirements will be implemented during the design, installation, and testing of the Electrical Switchgear Building fire protection systems.

\subsection{CODES AND STANDARDS}

This section lists the codes and standards used in the development of this Technical Report.

\subsubsection{Code of Federal Regulations}

29 Code of Federal Regulations (CFR) 1910 Subpart L, Labor: Occupational Safety and Health Fire Protection

29 CFR 1910.38 Subpart E, Labor: Occupational Safety and Health Standards - Means of Egress 


\subsubsection{Public Laws and Codes}

Americans for Disability Act (ADA), Accessibility Guidelines for Buildings and Facilities

\subsubsection{U. S. Department of Energy}

DOE Order 420.1, Change 3, Facility Safety

DOE G 440.1-5, Implementation Guide for Use with DOE Orders 420.1 and 440.1 Fire Safety Program

DOE Order 5480.7A, Fire Protection

\subsubsection{National Fire Protection Association (NFPA)}

NFPA 1, Fire Prevention Code

NFPA 10, Standard for Portable Fire Extinguishers

NFPA 13, Standard for the Installation of Sprinkler Systems

NFPA 22, Standard for Water Tanks for Private Fire Protection

NFPA 24, Standard for the Installation of Private Service Fire Mains and Their Appurtenance

NFPA 70, National Electrical Code

NFPA 72, National Fire Alarm Code

NFPA 90A, Standard for the Installation of Air Conditioning and Ventilation Systems

NFPA 101, Life Safety Code

\subsubsection{International Conference of Building Officials (ICBO)}

Uniform Building Code

\subsubsection{International Fire Code Institute (IFCI)}

Uniform Fire Code

\subsubsection{Underwriters Laboratories (UL), Inc.}

Fire Protection Equipment Directory

\subsubsection{Factory Mutual Research Corporation (FMRC)}

Approval Guide 


\subsection{PROCEDURES}

AP-2.21Q, Quality Determinations and Planning for Scientific, Engineering and Regulatory Compliance Activities.

AP-3.11Q, Technical Reports

AP-ESH-004, Occupational Safety and Health Program

AP-ESH-008, Hazards Analysis System

LP-ESH-010-M\&O, Emergency Management

QAP-2-3, Classification of Permanent Items

DOE/RW-0333P, Quality Assurance Requirements and Description

\section{ASSUMPTIONS}

\subsection{WATER}

It is assumed there is an adequate water supply from the non-potable storage tank on Exile Hill to meet the demand of the sprinkler systems and fire hydrants installed at the Electrical Switchgear Building. (See Figure 1, ESF Electrical Switchgear Building Fire Protection Plan, for the referenced hydraulic data.)

This assumption is based on the fact that the automatic controls for the Raw Water System were not installed. The Raw Water System is manually operated and supplies water to the non-potable storage tank on Exile Hill. Filling the Non-Potable Water Tank is performed by visual inspection and manually operating the pumps at J-13 Well; the single pump at the Booster Pump Station is filled by operations personnel. No visual monitoring of the Non-Potable Water Tank is performed during non-working hours.

The Non-Potable Water Tank, distribution piping system supplying the sprinkler systems and fire hydrants, and sprinkler systems were designed, installed, and tested per the baseline engineering document and with NFPA 13, Standard for the Installation of Sprinkler Systems; NFPA 22, Standard for Water Tanks for Private Fire Protection; and NFPA 24, Standard for the Installation of Private Fire Service Mains and Their Appurtenances, respectively. The system was sized in accordance with the Water Supply Analysis, B00000000-01717-0200-00074, REV 01 .

Operations and Maintenance testing and inspection records of the sprinkler systems, fire hydrants, and fire extinguishers are available in the project records. 


\subsection{HIGH VALUE PROPERTY}

For the purposes of this Technical Report, high value property is defined as property that has a replacement cost in excess of $\$ 1,000,000$. This definition is consistent with high value property in DOE Order 420.1, Change 2.

\subsection{OCCUPATIONAL SAFETY AND HEALTH}

The Electrical Switchgear Building is designated as an operating facility with public access. The appropriate code for the Electrical Switchgear Building is 29 CFR 1910.

\section{ANALYSIS}

\subsection{INTRODUCTION}

The Electrical Switchgear Building supports ESF construction, operation activities, and Yucca Mountain Site Characterization Project outreach activities located at the North Portal Pad.

The approach taken to complete this Technical Report involved a site walk-down of the Electrical Switchgear Building. A description of the building and its construction, a description of the installed fire protection features, and the identification of fire hazards that may involve this building and its fire areas are included in this Technical Report. After the data were collected, an analysis was performed to determine if the fire safety objectives identified in Section 1 have been satisfied.

\subsection{CONSTRUCTION}

\subsubsection{Structure}

The Electrical Switchgear Building is a steel, pre-engineered structure. The South Fire Area contains a mechanical/janitor room with associated equipment, water/ice service room, sprinkler riser room, restrooms, mine rescue operations room, outreach multipurpose area, and storage room. The North Fire Area will house the future Craft Shop. The building is 140 feet long by 60 feet wide with a 16-foot eave height. (See Figure 1 for the building drawings.)

The building is located on the surface of the ESF North Portal site, approximately 280 feet from the portal entrance. The mine water potable storage tank is approximately 80 feet north of the building. The drill bit shed is adjacent to the southeast corner of the building. The 5/7 MVA transformer (\#A01122) is 36 feet south of the Electrical Switchgear Building.

\subsubsection{Construction Type}

The building is of Type II noncombustible construction per the Uniform Building Code, Chapter 6 (ICBO 1997). The outreach multipurpose area, mine rescue area, and restrooms have asbestosfree vinyl composite floor tile. Unfinished floors are concrete treated with a sealer or hardener. The outreach multipurpose area and mine rescue area have acoustical ceiling tiles, and the 


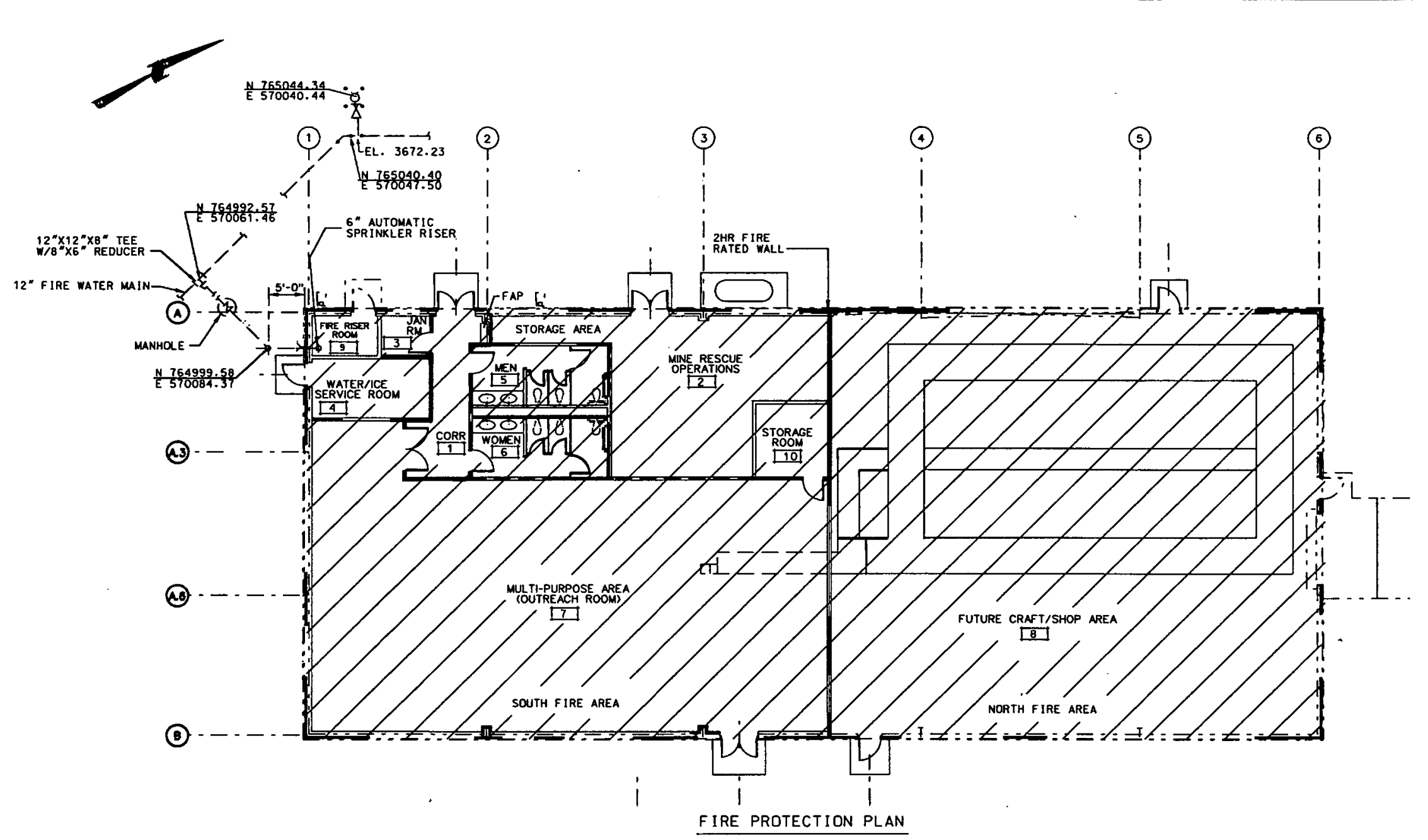

LEEEND

(8) VaLVE IN PIT

$Y$. FIRE DEPARTIENT SIA SESE CONNECTION

ERA Fire alarm panel

FIRE PROTECTION PLAN

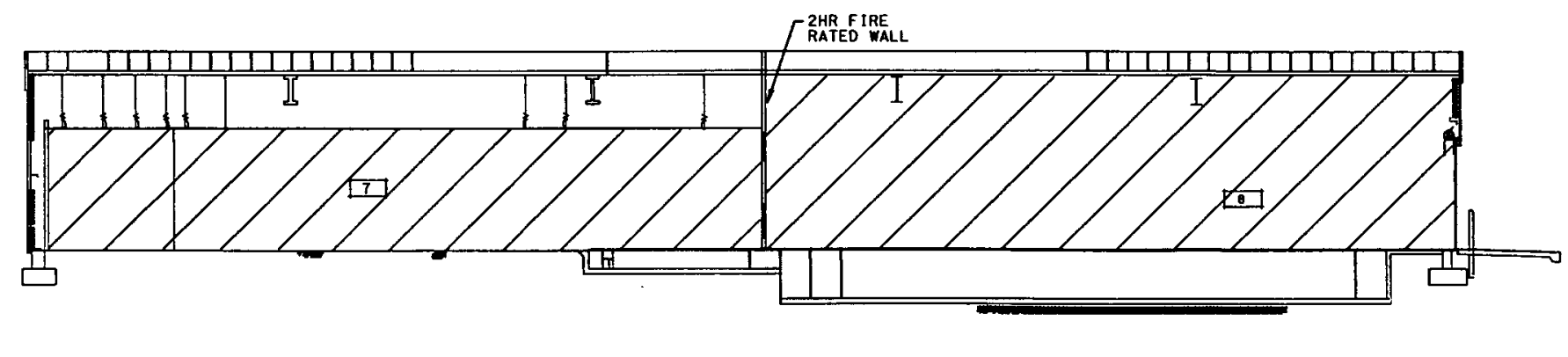

SECIION LOOKING WESI

wear 
restrooms have gypsum wallboard ceilings. The building complies with the Americans For Disability Act, Accessibility Guidelines for Buildings and Facilities.

\subsubsection{Occupancy Type}

The building design is based on an A3/B4 mixed occupancy classification per the Uniform Building Code, Volume 3 (ICBO 1997). This classification requires a two-hour fire rated barrier between the two occupancies.

\subsubsection{Suppression System}

The automatic sprinkler system installed in the Electrical Switchgear Building is a wet pipe sprinkler system. The density requirements are classified as an ordinary hazard, Group 2, occupancy in accordance with the Standard for the Installation of Sprinkler Systems (NFPA 13, Section 2-1.2.2).

\subsubsection{Egress Requirements}

The egress requirements are based on ordinary hazard industrial occupancy in accordance with NFPA 101, Life Safety Code, and the Americans For Disability Act, Accessibility Guidelines for Buildings and Facilities.

\subsection{MITIGATION}

The mitigations identified in this section are applicable to the North Fire Area and the South Fire Area.

\subsubsection{Active Systems}

The building is of a noncombustible construction and is fully equipped with an automatic wet pipe sprinkler system. The building has manual pull stations installed adjacent to all exits. In addition, portable fire extinguishers are installed where required.

\subsubsection{Passive Systems}

The future Craft Shop area, housed in the North Fire Area, is separated from the remainder of the building with a two-hour fire rated wall. All penetrations through this wall are sealed with the appropriate fire rated sealant, door, or damper. Electrical wiring is installed in accordance with NFPA 70, National Electrical Code.

\subsubsection{Fire Department Response}

The Area 23 response time would be approximately 45 minutes with three fire fighters, a 1,500gallon tanker, and a 1,250-gallon-per-minute pump.

\subsubsection{Life Safety Considerations}

Each fire area is provided with a minimum of two exits in accordance with NFPA 101. The maximum travel distances and common paths of travel are in compliance with NFPA 101, 
Chapters 5 and 28. Smoke detection, where required, is provided to shut down air handling equipment in accordance with NFPA 90A, Standard for the Installation of Air Conditioning and Ventilation Systems.

\subsubsection{Special Considerations}

The Electrical Switchgear Building, designed to Uniform Building Code requirements (ICBO 1997), provides reasonable mitigation from natural hazards such as earthquake, flood, lightning, wind, etc., as expected for the area. The building contains no materials that have the potential to cause a toxic, biological, or radiation incident.

\subsection{HIGH VALUE PROPERTY}

The Electrical Switchgear Building has been identified as high value property. Loss of the building and its contents would result in a loss in excess of $\$ 1,000,000$. The Electrical Switchgear Building has been valued at approximately $\$ 2,500,000$. Within the individual fire areas, the Craft Shop equipment has been valued at $\$ 100,000$, the Mine Rescue equipment at $\$ 50,000$, and the Outreach area at $\$ 25,000$.

\subsection{FIRE HAZARDS}

"Any situation, process, material, or condition that, on the basis of applicable data, may cause a fire or explosion or provide a ready fuel supply to augment the spread of intensity or the fire or explosion and that poses a threat to life or property." This is the definition of a fire hazard as described in NFPA 1, Fire Prevention Code.

Fuel sources in each fire area could include, but not be limited to, combustible and flammable liquids, wiring insulation, paper, and wood. Combustible liquids include hydraulic fluid, compressor oil, grease, and lubricating oil. Ignition sources may include faulty electrical equipment, woodworking operations, engine heat, and friction.

Typically, all materials used by craft personnel are stored properly in containers, cabinets, or areas.

\subsubsection{North Fire Area - Craft Shop Area}

The fire hazards located in the future Craft Shop area consist of a small switchgear cabinet and minor cabling, a drill press, electrical cabinets, and workbenches. Transient combustibles, including wood, will be kept to a minimum. Dust control equipment will be provided as needed.

\subsubsection{South Fire Area}

\subsubsection{Mine Rescue Operations Room}

These rooms contain sinks, refrigerators, oxygen cylinders, resuscitators, and storage shelves. Transient combustibles include paper and general office supplies. Oxygen cylinders shall be stored in accordance with the requirements of the Uniform Fire Code (IFCI 1997). Transient combustibles will be kept to a minimum through good housekeeping practices. 


\subsubsection{Outreach Multipurpose Area}

This room houses displays and computer and video equipment, along with chairs and tables.

\subsubsection{Other Rooms}

The remaining rooms located in the Electrical Switchgear Building include the restrooms, mechanical equipment, janitor's room, and fire riser room. The fire hazards are minor. The mechanical equipment room has small quantities of lubricants. The remaining rooms contain transient combustibles, including paper and small quantities of cleaning solutions.

\subsection{ANALYSIS OF FIRE HAZARD SCENARIOS}

Based on the fire hazards listed in Subsection 7.5, several potential fire scenarios can be postulated. In all scenarios except for failure of the automatic wet pipe sprinkler system, the projected fire loss is less than $\$ 1,000,000$. An automatic, wet pipe sprinkler system is provided in the Electrical Switchgear Building. In addition, the Electrical Switchgear Building has a manual alarm system installed that sounds local alarms and sends a signal to the Nevada Test Site (NTS) fire department.

\subsection{LIFE SAFETY CONSIDERATIONS}

This section evaluates the life safety considerations, as described in NFPA 101, for personnel who occupy the Electrical Switchgear Building.

The Electrical Switchgear Building has emergency lighting, an automatic wet pipe sprinkler system, and a manual fire alarm system. In addition, in the event of a fire, local fire alarms will sound throughout the Electrical Switchgear Building and send a signal to the NTS fire department. Portable fire extinguishers are installed throughout the Electrical Switchgear Building to fight fires in their incipient stages.

\subsection{FIRE PROTECTION FEATURES}

\subsubsection{Fire Suppression and Extinguishing}

\subsubsection{Automatic Sprinkler System}

An automatic wet pipe sprinkler system is provided throughout the building. The system is hydraulically designed and complies with NFPA 13, Section 7-2.3. (See Figure 1 for the hydraulic data.) The North Fire Area houses the future Craft Shop area and is sprinklered as an ordinary hazard, Group 2. Water flow alarms and supervisory switches interface with the fire alarm system, and sound audible and visual signals in the protected areas. The North Fire Area has a dedicated valve and water flow switch. 


\subsubsection{South Fire Area Sprinkler System}

The South Fire Area is provided with an automatic wet pipe sprinkler system throughout as an ordinary hazard, Group 2. Sprinkler piping supplying the South Fire Area has a separate valve and a dedicated water flow switch.

\subsubsection{Portable Fire Extinguishers}

Portable fire extinguishers are installed and distributed throughout the North and South Fire Areas to comply with NFPA 10, Standard for Portable Fire Extinguishers.

\subsubsection{Fire Water Supply and Distribution Piping}

\subsubsection{Area 25 Well Water}

Well water at Area 25 of the Nevada Test Site is pumped to the ESF construction and fire water storage tank. The water supply for the permanent fire protection installation is provided with a dedicated portion of the combined fire and construction water tank with sufficient capacity, as required by DOE Order 420.1 , Change 2 . The fire water distribution piping has a minimum earth cover of three feet. The branch connection to the main is within 40 feet of the ESF buildings.

\subsubsection{Fire Water Supply System}

The fire water supply system is separate from the potable water supply. All above grade fire protection piping subject to freezing conditions are insulated against freezing.

\subsubsection{Supply Adequacy}

The sprinkler system hydraulic analysis evaluates the adequacy of the proposed supply including flow, residual pressure, duration, and reliability, in accordance with the requirements of NFPA 13, Section 7-2.3. (See Figure 1.) The fire sprinkler subcontractor will provide the sprinkler.

\subsubsection{Sprinkler System Interface}

The interface between the building sprinkler system and the fire water distribution piping is at the flanged connection located in the fire riser room, approximately 12 inches above the floor. (See Figure 1.)

\subsubsection{Sprinkler System Components}

All components of the sprinkler system are either listed in the Underwriters Laboratories, Inc., Fire Protection Equipment Directory or the Factory Mutual Approval Guide.

\subsubsection{Design and Installation Requirements}

The design and installation of the buried distribution piping, including fire hydrants, meet the requirements of NFPA 24. This is based on the fact that the system was designed, installed, and 
tested by qualified personnel. There are no controlled Management and Operating Contractor asbuilt drawings for the buried non-potable water piping.

\subsubsection{Piping Size}

Fire water distribution piping is sized for the largest fire flows anticipated and in no case is less than eight inches in diameter. Supply piping to the automatic sprinkler system is at least as large as the system riser. The fire water distribution system was analyzed to verify the flows and pressures available. (See the Water Supply Analysis and hydraulic data provided on Figure 1.)

\subsubsection{Fire Detection and Alarm System}

\subsubsection{Fire Alarm Systems}

The design and installation of the fire alarm system complies with NFPA 72, National Fire Alarm Code. All detection and alarm devices have Underwriters Laboratories, Inc., listed components or are Factory Mutual approved.

\subsubsection{Fire Alarms}

Flow switches are installed in the sprinkler piping to actuate alarms. There are local alarms for the building occupants, and a remote alarm signal is sent to the site fire dispatcher located in Mercury, Nevada. The fire alarm panel is located in the vestibule of the South Fire Area near the main entrance of the building. (See Figure 1.) The fire alarm panel serves both the North and South Fire Areas. An alarm in either area will actuate the evacuation signals for both areas.

\subsubsection{Fire Alarm Panel}

The fire alarm panel supervises the manual pull stations, water flow switches on the sprinkler system, valve tamper switches located on all fire system control valves, and performs selfdiagnosis on its internal circuits. The supervisory signal will be sent to the NTS fire department in Mercury, Nevada. The panel is provided with an integral 72-hour battery backup.

\subsection{POTENTIAL FOR A TOXIC, BIOLOGICAL, AND/OR RADIATION INCIDENT DUE TO A FIRE}

The potential for a toxic, biological, and/or radiation incident due to a fire is not considered significant because:

- Most materials selected for construction are essentially inert.

- Burning electrical cables can emit potentially toxic gases as products of combustion. The risk of combustion occurring is low due to the expected use of fire resistant cables.

- Biological and radioactive materials are not present.

The North Fire Area houses future Craft Shop areas, utilizing ordinary combustible materials as well as cable and motors. The South Fire Area contains storage for mine rescue that includes 
compressed air cylinders, breathing apparatuses, protective clothing, and storage and analytical equipment. The South Fire Area also contains the mechanical equipment room and multipurpose area.

\subsection{NATURAL HAZARDS}

The impact on fire safety from natural hazards, such as earthquakes, floods, wind, dusty environment, and expected temperature and humidity, are limited and was considered during the design phase of the systems.

The automatic, wet pipe sprinkler system installed in the Electrical Switchgear Building was designed and installed in compliance to NFPA 13 for areas subject to earthquakes.

\subsection{DAMAGE POTENTIAL}

The response time of the NTS fire response unit (CRWMS M\&O 2000a) during off working hours is such that the structures and equipment involved would be a total loss prior to the unit reaching the Electrical Switchgear Building. It is not anticipated that a fire burning unchecked could cause damage in excess of $\$ 2,500,000$. The North and South Fire Areas are segregated by a two hour fire rated wall. A fire in one area is not expected to be of such magnitude and duration to cause damage to both areas. Loss of equipment in the North Fire Area is not expected to exceed $\$ 100,000$. Loss of equipment in the South Fire Area is not expected to exceed $\$ 75,000$.

\subsection{SAFETY CLASS EQUIPMENT}

No safety class systems or equipment have been identified as important to radiological safety or waste isolation at the Electrical Switchgear Building. The North Fire Area houses equipment for Craft Shop areas, and the South Fire Area houses Mine Rescue equipment and Outreach displays.

\subsection{CRITICAL PROCESS EQUIPMENT}

No process equipment has been identified as being critical at the Electrical Switchgear Building. The North Fire Area houses equipment for Craft Shop areas, and the South Fire Area houses Mine Rescue equipment and Outreach displays.

\subsection{EMERGENCY PLANNING}

The operating contractor has the responsibility for developing and maintaining the emergency action plan in accordance with 29 CFR 1910.38 Subpart E, Labor: Occupational Safety and Health Standards - Means of Egress. The OCRWM procedure AP-ESH-04, Occupational Safety and Health Program, complies with this requirement.

\subsection{FIRE DEPARTMENT/BRIGADE}

The response time of the NTS fire response unit (CRWMS M\&O 2000a) during off working hours is such that the structures and equipment involved would be a total loss prior to the unit 
reaching the Electrical Switchgear Building. The project does not have a trained fire brigade made up of site personnel. Site personnel have received cursory training on the use of fire extinguishers for incipient fires only, but have not been trained as a fire brigade.

\subsection{RECOVERY POTENTIAL}

The ability to recover from a credible fire is considered reasonably acceptable. The installed fire protection systems and facility separations will limit physical damage to the facility and its contents.

Unacceptable levels of environmental damage, caused by a credible fire, are postulated only if the fire protection systems fail to perform as designed and fire spreads to the local vegetation.

\subsection{SECURITY AND SAFEGUARDS}

There are no security requirements or concerns related to fire protection. Since all the facilities located at the Yucca Mountain Site Characterization Project are located within the same security area, no security violations have been identified.

\subsection{EXPOSURE FIRE POTENTIAL AND THE POTENTIAL FOR FIRE SPREAD BETWEEN TWO FIRE AREAS}

An exposure fire potential exists because of equipment currently located adjacent to the north end of the building. This equipment has drip pans and contains hydraulic fluid possessing an exposure fire risk. The potential for fire spread between two fire areas is not a factor at the Electrical Switchgear Building. The Electrical Switchgear Building does not pose a fire hazard to the surrounding facilities (see Surface Fire Hazards Analysis Technical Report-Constructor Facilities).

\subsection{EFFECTS OF SIGNIFICANT FIRE SAFETY DEFICIENCIES ON FIRE RISK}

Due to the remote location of the Yucca Mountain Site Characterization Project from the NTS fire response unit, the response time is insufficient to minimize the loss from fire. If a fire occurs during the off working hours, those structures and equipment involved would be a total loss prior to the response unit reaching any of the sites.

\section{CONCLUSIONS AND RECOMMENDATIONS}

\subsection{CONCLUSIONS}

This Technical Report identifies fire hazards and fire protection features that mitigate the damage that could occur as a result of a fire. It confirms that objectives identified in Section 1 have been met for each fire area. 


\subsubsection{Fire Occurrence}

To minimize the occurrence of a fire or related events, ignition sources are minimized and combustibles are either contained within transportainers or separated from each other. Flammable liquids are stored within flammable liquid storage cabinets when not in use. Fire areas are separated by a two hour fire rated barrier.

\subsubsection{Radioactive and Hazardous Materials}

Neither fire area has radioactive materials. In addition, hazardous materials are controlled and properly stored in both fire areas to minimize the threat to the health and safety of the employees, the public, and the environment.

\subsubsection{Vital DOE Programs}

The facilities identified in this Technical Report, if lost, would not interrupt vital DOE programs.

\subsubsection{Property Loss}

Property losses from a fire and related events in either fire area do not exceed defined limits established by DOE.

\subsubsection{Critical Process Controls and Safety Class Systems}

No critical process controls or safety class systems have been identified in either fire area.

\subsection{RECOMMENDATIONS}

The building is being equipped with an automatic wet pipe sprinkler system throughout, and a two-hour firewall will separate the future Craft Shop areas from the remainder of the building. This should reduce the risk of a credible fire loss to below the high property value limit of $\$ 1,000,000$.

The hydraulic reference point data shown in Figure 1, Note 13, are verified on an annual basis by the NTS Fire Department. The fire sprinkler subcontractor will design and install the automatic sprinkler system based on the hydraulic reference point in Figure 1.

\section{INPUTS AND REFERENCES}

\subsection{REFERENCED DOCUMENTS}

The information contained within this Technical Report is based on information obtained during a site walkdown conducted on May 16, 2000. The documents referenced are listed in Subsections 9.1.1 and 9.1.2. 


\subsubsection{Documents Cited}

DOE 2000. Quality Assurance Requirements and Description. DOE/RW-0333P, Rev. 9. Washington, D.C.: U.S. Department of Energy, Office of Civilian Radioactive Waste Management. ACC: MOL.19991028.0012.

CRWMS M\&O 2000a. Surface Fire Hazards Analysis Technical Report-Constructor Facilities, BAB000000-01717-5705-00016, Rev. 00, ACC: MOL.20001106.0244.

CRWMS M\&O 2000b. Technical Work Plan for Test Facilities Design FY01 Work Activities. TWP-MGR-MD-000012 REV 00. Las Vegas, Nevada: CRWMS M\&O. ACC:

MOL.20001108.0004

CRWMS M\&O 1999. Complete Accurate Technical Baseline. Activity Evaluation. Las Vegas, Nevada: CRWMS M\&O. ACC: MOL.19991018.0008.

YMP 1997. Exploratory Studies Facility Design Requirements. YMP/CM-0019, Rev. 2, ICN 1. Las Vegas, Nevada: Yucca Mountain Site Characterization Office.

ACC: MOL.19980107.0544; MOL.19960926.0065.

CRWMS M\&O 1996, Water Supply Analysis, B00000000-01717-0200-00074, Rev. 01,Las Vegas, Nevada: CRWMS M\&O ACC: MOL.19960729.0343.

\subsubsection{Codes, Standards, Regulations, and Procedures}

DOE (U.S. Department of Energy) Order 420.1, Change 2. 1996. Facility Safety. Washington, DC: U.S. Department of Energy. Readily available.

DOE G-420.1/B-0, G-440.1/E-0. 1995. Implementation Guide for Use with DOE Orders 420.1 and 440.1 Fire Safety Program. Washington, D.C.: U.S. Department of Energy. Readily available.

29 CFR (Code of Federal Regulations) 1910 Subpart L. 1988. Labor: Occupational Safety and Health Standards - Fire Protection. Readily available.

29 CFR Subpart E. 1997. Labor: Occupational Safety and Health Standards - Means of Egress. Washington, D.C.: U.S. Department of Labor. Readily available.

NFPA (National Fire Protection Association) 1. 1997. Fire Prevention Code. Quincy, Massachusetts: National Fire Protection Association. TIC: 238744.

NFPA 10. 1998. Standard for Portable Fire Extinguishers. Quincy, Massachusetts: National Fire Protection Association. TIC: 241333.

NFPA 13. 1994. Standard for the Installation of Sprinkler Systems. Quincy, Massachusetts: National Fire Protection Association. TIC: 103082. 
NFPA 22. 1994. Standard for Water Tanks for Private Fire Protection. Quincy, Massachusetts: National Fire Protection Association. On order. Library Tracking Number: 248385.

NFPA 24. 1995. Standard for the Installation of Private Fire Service Mains and Their Appurtenances. Quincy, Massachusetts: National Fire Protection Association. TIC: 241328.

NFPA 70. 1998. National Electrical Code. Quincy, Massachusetts: National Fire Protection Association. TIC: 240528.

NFPA 72. 1999. National Fire Alarm Code. Quincy, Massachusetts: National Fire Protection Association. TIC: 247112.

NFPA 90A. 1996. Standard for the Installation of Air Conditioning and Ventilation. 1996 Edition. Quincy, Massachusetts: National Fire Protection Association. TIC: 240301

NFPA 101. 1997. Life Safety Code. (with Tentative Interim Amendment). Quincy, Massachusetts: National Fire Protection Association. TIC: 248386.

IFCI (International Fire Code Institute). 1997. Uniform Fire Code. Volume 1. $10^{\text {th }}$ Edition. Whittier, California: International Fire Code Institute. TIC: 246540.

ICBO (International Conference of Building Officials). 1997. 1997 Uniform Building Code. Three volumes. Whittier, California: International Conference of Building Officials. TIC: $233816 ; 233817 ; 233818$.

Underwriters Laboratories 1996. Fire Protection Equipment Directory 1996. Northbrook, Illinois: Underwriters Laboratories. TIC: 238938.

FM (Factory Mutual). 1999. Factory Mutual Approval Guide. Norwood, Massachusetts: Factory Mutual System. On Order. Library Tracking Number: 248591.

36 CFR 1191. 1998. Parks, Forests, and Public Property: Americans with Disabilities Act (ADA) Accessibility Guidelines for Buildings and Facilities. Readily available.

AP-3.11Q, Technical Reports

AP-2.13Q, Technical Product Development Planning

QAP-2-3, Classification of Permanent Items

AP-ESH-004, Occupational Safety and Health Program

AP-ESH-008, Hazards Analysis System 